\title{
Divan Şiirinde Geçen Musiki Istılahlarına Dair Genel Bir Tasnif Denemesi
}

\section{An Attempt on a General Classification of the Musical Terms in Divan Poetry}

\author{
Emrah Bilgin ${ }^{1}[(]$
}

${ }^{1}$ Dr. Öğr. Üyesi, Ardahan Üniversitesi, İnsani Bilimler ve Edebiyat Fakültesi, Türk Dili ve Edebiyatı Bölümü, Ardahan, Türkiye

ORCID: E.B. 0000-0002-7221-8573

Sorumlu yazar/Corresponding author: Emrah Bilgin,

Ardahan Üniversitesi, İnsani Bilimler ve Edebiyat Fakültesi, Türk Dili ve Edebiyatı Bölümü, Ardahan, Türkiye

E-mail: bilginemrah@gmail.com

Başvuru/Submitted: 02.10.2020 Revizyon Talebi/Revision Requested: 27.10.2020

Son Revizyon/Last Revision Received:

12.11.2020

Kabul/Accepted: 12.11 .2020

\section{Atuf/Citation:}

Bilgin, E. (2020). Divan şiirinde geçen musiki ıstılahlarına dair genel bir tasnif denemesi. TUDED 60(2), 517-537.

https://doi.org/10.26650/TUDED2020-804293

\section{ÖZET}

Klasik Türk edebiyatı tarihinde edebiyat ve şiirin yanında musiki sahasında da ilim sahibi olan șairlerin arasında ilm-i musikinin unsurları ile șiirler kaleme alan ve böylece musiki ıstılahlarının şiire girmesine vesile olmuş çok sayıda divan şairi vardır. Musiki makamları, usulleri, çalgıları ile çalgıların aksamı, şiir dilinde en çok kullanılmış olan musiki ıstılahlarıdır. Bu sstılahlar içerisinde adı en çok geçenler ise makamlar ile çalgılardır. Bu çalışmada makam ve çalgıların her biri, esasında şiire farklı anlamlar kattığından türlerine ve kullanıldıkları yere göre de kendi içinde sınıflandırılmıştır. Musiki icrasında adı geçen şahıslar ve mekânlar da şu ana kadarki incelemelerde tespit edilebildiği kadarıyla yine kendi içinde tasnif edilmiştir. Tüm bu ıstılahların haricinde musiki 1stılahları ile kurulmuş deyimler de kendi içinde bölümlere ayrılmıştır. Musikiye dair yapılan araștırmalara katkı sağlaması amaçlanan bu çalışmada divan şiirinde adları geçen musiki ıstılahlarına dair yeni bir tasnif yapılmıştır. Buradaki temel gaye de sadece bahsi geçen istılahlara dair bir sınıflandırmanın yapılmasıdır. $\mathrm{Bu}$ istılahların klasik şiir geleneği içerisinde ne şekilde incelenebileceğine dair henüz netleşmiş bir kanaat yoktur. Bu nedenle bu çalışma ile musiki ıstılahları ile ilgili böyle bir bahsin olduğu konusunda endişe oluşturulması da amaçlanmıştır. Böylece klasik şiir geleneği içerisinde musiki ıstılahlarının ne kadar önemli bir yerde olduğuna dair pek çok husus ortaya konulabilecektir.

Anahtar Kelimeler: Klasik Türk edebiyatı, klasik Türk musikisi, şiir ve müzik, musiki sstılahları, Türk müziği makamları

\section{ABSTRACT}

In the history of classical Turkish literature, there are many poets who have knowledge in the field of music, who have been instrumental in the introduction of musical terms into poetry because they wrote poems with the elements of music. Musical tunes, tempos, instruments and parts of instruments are the most used musical terms in the language of poetry. Musical tunes and and instruments are also classified separately within each of them, as they add different meanings to the poem according to their genres and where they are used. In addition, terms other than these titles related to performing music were also evaluated. The persons and places mentioned in the musical performance have also been classified within themselves, as far as they can be determined in the studies so far. In this study, which is intended to contribute to the researches on music, a new classification has been made regarding the musical terms mentioned in the divan poetry. The main purpose here is to make a classification only for the aforementioned terms. There is no clear conclusion as to how these terms can be examined within the classical poetry tradition. Therefore, it is aimed to raise concerns that there is such a bet regarding musical terms.

Keywords: Classical Turkish literature, classical Turkish music, poem and music, musical terms, musical modes of Turkish music 


\section{EXTENDED ABSTRACT}

In classical poetry, the concepts of various sciences were used as a source in poetry by poets who have cultural knowledge of those sciences. In this context, the artistic elements of the language were mostly seen in literature and music, two important branches of fine arts.

Musical terms are one of the important elements of classical poetry. The fact that there are so many musical elements in classical poetry, and there are many works composed with classical poetry forms in music are also a proof of how much the two sciences are nourished from each other.

This study, which examines the musical elements in divan poetry, is about the classification of the elements in divan related to music. As far as it can be determined, the most important and known classification on the use of musical elements in divan poetry; music modes, musical instruments, other parts of musical instruments, other elements related to music and expressions related to music.

In this study, first of all, poems containing these elements rather than musical elements are classified. The items in the above classification are included as some items under the subtitle of a title in the new classification. In addition, methods were added to these elements; besides, instruments, persons, places and idioms are also divided into classes as they are used differently according to their genre in the poem. The musical terms have been reclassified with the data obtained so far. The first title of the classification includes musical modes. The music modes are divided into three categories: simple modes, delivered modes and compound modes. Secondly, musical methods are given. The third heading of the classification includes musical instruments. This title has been examined in five groups as wired instruments, string instruments, wind instruments, percussion instruments and keyboard instruments. Later, the parts of the musical instruments were given as a separate title. The terms regarding the performance of music are the next title. After this title of the classification, the persons mentioned in the performance of music and then the places mentioned in the music performance were examined. The persons mentioned in musical performance; they were divided into four groups: people who played an instrument during music performance, people who sing while performing music, people who played music, and people who were in the assembly during music performance. The venues mentioned in the performance of music are places of entertainment and sufi assemblies. In the last heading of the classification, there are idioms established with musical terms. This part is divided into seven sections within itself: idioms formed by musical modes, idioms formed with musical methods, idioms formed from musical instruments, idioms formed with parts of musical instruments, idioms related to the performance of music, idioms related to the music islamic monasteries.

The seventh and eighth titles of the classification are related to the names of the persons and places mentioned in the musical performance. The ninth title is on the idioms related to the musical terms and performance given by M. Nejat Sefercioğlu. In the article, the classification was tried to be enriched with sub-headings in these three headings. 
In the classification, the terms of music are classified primarily as the modes, methods, instruments, parts of the musical instruments, and the performance of music. In addition, since the terms of music can be included in the same couplet, they have been evaluated together in some examples in the study. However, as it is not possible to give many examples about each musical element within the limited framework of the article, it is contented to give a small number of examples. In addition, some couplets containing musical elements were used in the interpretation of couplets.

Apart from some studies on the musical terms in the classical Turkish literature texts, it has been observed that researches generally include determinations about which musical terms are included in the works. There is partial information in the studies about what kind of meaning they provide in a poem containing the aforementioned elements or it is seen that musical elements are generally examined in terms of literary arts. In this study, the musical terms mentioned in the divan poetry are classified. Thus, it is thought that the terms determined in verse or prose works will be evaluated under a title given in the classification, and thus a systematic literature containing a wide range of material on these terms will emerge over time.

This classification of the musical terms in divan poetry and the general features of each classification will contribute to the understanding of the classical literary texts. However, detailed information about these elements, which contain a wide range of materials, will be possible with a more comprehensive study. 


\section{GíRIŞ}

Klasik şiirde çeşitli ilimlerin kavramları, o ilimlerin kültürel birikimlerine sahip olan şairler tarafından birer kaynak olarak şiir dilinde kullanılmıştır. Bu bağlamda dilin sanatsal unsurları ise güzel sanatların iki önemli dalı olan edebiyat ve musikide daha çok görülmüştür.

Türk musikisinde bestelenen eserlerin önemli bir kısmı, klasik dönemde ortaya konmuştur. Edebiyat ve musikide zirveyi ifade etmede kullanılan "klasik" kelimesi ile belirtilen bu dönemde şairlerin divanlarında asırlar boyunca musiki de her bir unsuru ile şiir dilinde kendine yer bulmuştur.

Tespit edilebildiği kadarıyla divan şiirinde musiki ile ilgili unsurların kullanılışı üzerine yapılan en önemli ve bilinen tasnif M. Nejat Sefercioğlu'na (1999, s. 649) aittir. Osmanlı Ansiklopedisi'nde yer alan bu çalışmada musiki unsurlarının şiirde kullanılışı;

a) Musiki Makamları

b) Musiki Aletleri

c) Usul Vurma Aletleri

d) Musiki Aletlerinin Diğer Aksamı

e) Musiki ile İlgili Diğer Unsurlar

f) Musiki ile İlgili Deyimler

şeklinde sınıflandırılmış ve her bir başlık altında örnek beyitler verilmiştir. Tasnifte yer alan bu unsurlar, yapılmaya çalışılan yeni sınıflandırmada da yer almaktadır. Ayrıca yeni tasnifte makamlar, çalgılar, şahıslar, mekânlar ve deyimler de kendi içinde kısımlara ayrılmıştır. Elde edilen tüm bu veriler ile musiki ıstılahlarına dair yeni sınıflandırma şu şekilde oluşturulmuştur:

1. Musiki Makamları

1.1. Basit Makamlar

1.2. Şed (Göçürülmüş) Makamlar

1.3. Mürekkep (Bileşik) Makamlar

2. Musiki Usulleri

3. Musiki Çalgıları

3.1. Mızraplı Çalgılar

3.2. Yaylı Çalgılar

3.3. Nefesli Çalgılar

3.4. Vurmalı Çalgılar

3.5. Tuşlu Çalgılar

4. Musiki Çalgılarının Aksamı 
5. Musikinin İcrası ile İlgili Istılahlar

6. Musiki İcrasında Adı Geçen Şahıslar

6.1. Sazendeler

6.2. Hanendeler

6.3. Raks Edenler

6.4. Diğer Şahıslar

7. Musiki İcrasında Adı Geçen Mekânlar

7.1. Eğlence Meclisleri

7.2. Tasavvufî̀ Meclisler

8. Musiki Istılahları ile Kurulmuş Deyimler

8.1. Musiki Makamları ile Oluşturulmuş Deyimler

8.2. Musiki Usulleri ile Oluşturulmuş Deyimler

8.3. Musiki Çalgılarından Oluşturulmuş Deyimler

8.4. Musiki Çalgılarının Aksamıyla Oluşturulmuş Deyimler

8.5. Musikinin İcrası ile İlgili Deyimler

8.6. Tekke Musikisi ile İlgili Deyimler

Tasnifte musiki ıstılahları kendi içerisinde öncelikle musikinin makamları, usulleri, çalgıları, çalgıların aksamı ve musikinin icrası ile ilgili ıstılahlar olmak üzere sınıflandırılmıştır. Ayrıca musiki 1stılahları, aynı beyit içerisinde yer alabildiklerinden çalışma içerisindeki kimi örneklerde birlikte değerlendirilmiştir. Ancak her bir musiki unsuru ile ilgili çok sayıda örnek vermek makalenin sınırlı çerçevesinde pek mümkün olmadığından az sayıda örnek vermekle yetinilmiştir.

Sınıflandırmanın yedinci ve sekizinci başlıkları, musiki icrasında adı geçen şahıs ve mekân adları ile ilgilidir. Dokuzuncu başlık ise Sefercioğlu'nun da ayrıca verdiği musiki ıstılahları ve icrasıyla alakalı deyimler üzerinedir. Makalede bu üç başlıkta da alt başlıklar ile tasnif daha zenginleştirilmeye çalışılmıştır.

Çalışmanın içerisinde kalın (bold) olarak verilen ıstılahlar makam adlarını, altı çizili olarak belirtilen ıstılahlar çalgı isimlerini ve eğik (italik) olan ıstılahlar da bu iki grubun dışındaki diğer istılahları göstermektedir.

Son yıllarda teknolojinin gelişmesi ve verilerin bilgisayar ortamına aktarılarak taranabilmesi ile yapılan araştırmalarda büyük kolaylıklar sağlanmıştır. Divanlar ile diğer ilgili eserlerden tarama yapılabilmekte ve bu sayede veri elde edilebilmektedir. Musikiye dair 1stılahlar da bu şekilde taranmış ve çok sayıda veri elde edilmiştir. Hem yapılan okumalardan hem de bu taramalardan elde edilen verinin çok az bir kısmı bu çalışmaya alınabilmiştir. Diğger yandan bu yazının amacı, divanlarda kaç musiki ıstılahının yer aldığı, şiirde kullanılan ıstılahların her birinin tespiti, sstılahların geçtiği beyit örneklerinin verilmesi veya bu beyit ya da şiirlerin 
yorumlanması da değildir. Tüm bunların tespit edilmesi için çok daha ayrıntılı bir çalışmaya ihtiyaç vardır. Başka bir ifadeyle bu konu ciltlerce kitap olabilecek mahiyettedir. Bunların dışında bu konunun ifadesinde çok geniş bir literatür taraması yapılması ve kaynakçanın da zenginleştirilmesi gerekmektedir. Ancak buradaki temel gaye sadece divan şiirinde adları geçen musiki ıstılahlarının genel başlıklarla tasnif edilmesidir.

Klasik şiirde musiki ıstılahlarının ne şekilde yer aldığına dair kimi çalışmalar yapılmıştır. ${ }^{1}$ Bazı çalışmalarda genellikle edebi sanat yönünden inceleme yapıldığı veya sadece bu unsurların tespitinde bulunulduğu görülmektedir. Bu çalışmada ise tespitten öteye gidilmeye çalışılarak bahsi geçen unsurların tasnifi amaçlanmıştır.

\section{Musiki Istılahları}

\section{Musiki Makamlari ${ }^{2}$}

Özel kuralları bulunan ve bir müzik sistemine esas olan belirli perdelerdeki notaların sıralanmasına dizi denir. Musiki makamları da bu dizilerden oluşurlar (Say, 1985, s. 446). Makam ise bir dizide durak ve güçlü sesin önemi belirtilmek ve uyulması gereken diğer kaidelere de bağlı kalınmak suretiyle nağmeler meydana getirerek gezinmeye denir. Bir dizide en önemli perdeler ise durak, güçlü ve asma karar perdeleridir (Özkan, 2017, s. 94).

Musiki makamları, kimi zaman çalgılar ve kimi zaman da usullerle birlikte aynı beyit içerisinde kullanılmışlardır. Bu tür şiirlerde esasında makam, çalgılar veya usuller birlikte değerlendirilmelidir. Bu noktada klasik şiir içerisinde makamlar ile diğer musiki unsurlarının kullanımının incelenebilmesi için tespit edilen unsurların sözlük ve mecaz anlamlarının dışında musiki nazariyatı içerisindeki karşılıklarının da dikkate alınması gereklidir. Örneğin musiki makamlarının bir kısmının yer adlarından alındığı bilinmektedir. Misalen hicaz, ırak, ısfahan ve nişabur makamları bu şekildedir. Musiki makamları, şiir dilinde tevriye ve iham gibi edebi sanatlar için uygun ıstılahlardır. Enderunlu Rasih'in kâr-ı nâtık formundaki şiirinde geçen;

Ehl-i tab'a pek muhâlifdir Hicâz'ın dilberi

Arturur sevdâsını halkın o vech-i esmeri (Yekbaş, 2014, s. 228)

1 Musiki ıstılahlarına dair çeşitli çalışmalar yapılmıştır. Bk. Arslan, 1992a; Arslan, 1992b; Çalka, 2008; Çetin, 2009; Erdoğan, 2010; Altunmeral, 2011; Tozlu, 2014; Aslan, 2017.

2 Musiki makam adlarına dair daha evvel yapmış olduğumuz "Klâsik Şiirde Manayı Sağlayan Bir Unsur Olarak Mûsikî Makamlarının Kullanılışına Dair Bazı Örnekler” (bk. Bilgin, 2019) başlıklı tebliğ çalışmasında bazı beyitler üzerinden kavramlara dair bilgi verilmiştir. Bu nedenle tekrara düşmemek gerektiği ve konunun çok sayıda örnekle izah edilmesi gerekliliği düşünülerek bu kısım, tebliğde bulunmayan başka örnekler üzerinden ifade edilerek yeniden tertip edilmiş ve tebliğdeki bilgilere başvurulmamıştır. İlgili tebliğde makamlar bu çalışmadaki şekliyle tasnif edilmemiş ve derinlemesine incelenmemiş; sadece birkaç örnek beyit üzerinden konuya değinilmiştir. 
beyti buna bir örnektir. Ahmet Avni Konuk'un kâr-1 nâtık formundaki şiirinde de yine benzer bir anlam taşıyan bir beyit bulunmaktadır. ${ }^{3}$

Makam adları, musiki unsurlarının klasik şiirde en çok kullanıldığı başlıca 1stılahlardır. Klasik edebiyatın ilk dönemlerinden itibaren musiki ilmini bilen şairlerin şiirlerinde makam adlarını kullandıkları görülmektedir. Örneğin musiki makamlarına şiirlerinde çokça yer vermiş olduğu görülen Kadı Burhaneddin'in divanında musikinin eski makamları da yer almaktadır. Şairin makam adlarına yer verdiği beyitlerden biri şöyledir:

\section{Ben râstî muhayyerem ol bir müberka'a}

Lutf ider ise bize nühüfte hicâz ola (Ergin, 1980, s. 423)

Klasik edebiyat şairlerinin divanları incelendiğinde herhangi bir makamın şiir diline ne zaman girmiş olabileceğine dair de bilgi edinilebilecektir. Mesela yukarıdaki beyitte adı geçen müberkaa makamı Türk musikisinde iki örneği olan bir makamdır (Öztuna, 2000b, s. 279). Ancak şairlerin divanlarında veya kâr-1 nâtıklarda ismi geçen bir makam olması, daha fazla örneğinin olabileceğini de düşündürmektedir.

Türk musikisinde makamlar, basit makamlar, şed (göçürülmüss) makamlar ve mürekkep (bileşik) makamlar şeklinde üç grupta incelenmektedir. Divan şiirinde adları geçen makamlar da bu tasnife göre sinıflandırılabilir.

\subsection{Basit Makamlar}

Türk musikinde basit makamların özelliklerini ihtiva eden 13 makam vardır. Bunlar; çargâh, buselik, kürdi, rast, uş̧ak, neva, hümayun, hicaz, uzzal, zirgûleli hicaz, karcı̆̆ar, basit suzinak ve hüseyni makamlarıdır (Öztuna, 2000a, s. 33). Klasik şiirde şimdiye kadarki tespitlere göre ismi en çok geçen makamlar bu kategoridedir. Örneğin Süleyman Nahifi'nin divanında yer alan;

Sûznâk olsa n'ola bülbülün âvâzeleri

İtdiği nağmede uşşâkdur âgâzeleri (Alpay, 1992, s. 513)

beytinde basit makamlardan ikisi yer almaktadır. "Bülbülün şakımasının suzinak [makamı] olmasında hayret edilecek bir şey yoktur. [Zira] sesinin ahenginde ilk olarak uşşak [makamı] vardır.” şeklinde diliçi çevrilebilecek olan beyitten anlaşılabileceği üzere de bülbülün sesinin suzinak makamında olduğu; ancak ötmeye uşşak makamında başladığı ifade edilmektedir. Bülbülün nağmesinin her ne kadar yakıcılığı olsa da ötmeye neşe ile başladığ 1 da bir anlam olarak düşünülebilir.

3 Hicaz makamının esmerliği ve bu makamın şiir dilinde kullanılmasına dair başka örnekler de vardır (Bir örnek için bk. Bilgin, 2019, s. 354). 


\section{2. Şed (Göçürülmüş) Makamlar}

Herhangi bir dörtlü ya da beşli makam dizisini kendi yerinden yani durağından alıp başka bir perde üzerine yani başka bir perdeyi durak kabul ederek aralıklarını bozmadan ve gerekli işaret değişikliklerini yaparak göçürmeye şed denmektedir. Başka makamlara göçürülmüş makamlar; çargâh, buselik, kürdi, zirgûleli hicaz, neveser ve segâh makamlarıdır. Bu makamlar göçürüldükleri yerde kimi yeni özellikler kazanarak kullanılmış ve böylece bunlara şed makamlar ya da göçürülmüş makamlar denmiştir. Ancak her bütün dizi ya da çeşniler, Türk musikisinde bulunan bütün sesler üzerine göçürülemezler. Örneğin segâh perdesinde uşşak çeşnisi yapılamaz (Özkan, 2017, s. 211-213).

Çok sayıda örneği olan şed makamların klasik şiirde de isimlerinin geçtiği görülmektedir. Sakıp Dede'nin;

Reh-i 'Irâk u Nihâvend'e şedd-i rahl itme

Ki tîh-i gerdiş-i bîhûde itmesün mahsur (Arı, 2018, s. 56)

beyti, şed makamların şiirde bu anlamıyla kullanıldığına dair önemli bir örnektir. "Irak ve Nihavent yoluna [doğru] yolculuğa çıkma ki boş yere çöllerde dolaşarak mahsur kalmayasın.” şeklinde diliçi çevirisi yapılabilecek olan beyitte trak ve nihavent kelimeleri, sahip oldukları yer adı anlamlarının dışında makam adı olarak düşünüldüğünde de şairin esasında nasihat ettiği ve yol gösterdiği anlaşılır. Irak makamı, bilindiği üzere mürekkep (bileşik) makamlardan biridir. Nihavent makamı ise buselik makamının rast perdesinde bir ton peste alınmış şeddidir (Öztuna, 2000d, s. 300). Şair de bu beyitte ırak makamından nihavent makamına göçürülemeyeceğini ifade etmiş olmalıdır.

Yukarıdaki beyit, bahsi geçtiği üzere şed makamlardan birinin musiki nazariyatı ile şiir dilinde yer aldığına dair bir örnektir. Bu tür beyitler ayrıca musikişinas şairlerin müzik bilgilerini şiir diline aktardıklarına dair daha detaylı örneklerdir.

\subsection{Mürekkep (Bileşik) Makamlar}

Farklı çeşni ve dizilerin birbirine geçkisinden ve bu geçkilerin özel kalıplar hâlinde tespitinden yani bir kişilik kazanması ile makam sayılmasından mürekkep (bileşik) makamlar ortaya çıkmıştır. Mürekkep makamların esası ise işte bu geçkilerdir. Katışık makamlar, bileşimli makamlar ve ekli makamlar olmak üzere üçe ayrılırlar (Özkan, 2017, s. 291).

Çok sayıda olan mürekkep makamların hangilerinin yaşadığı, hangilerinin terkedilemeyecek makamlar olduğu, hangilerinin kendine has bir hissiyat taşıdığı gibi hususlar üzerine bir değerlendirmede bulunmak da kolay değildir. Diğer yandan bu makamların pek çoğunun icra edilen tek bir örneği dahi bugüne ulaşamamıştır (Öztuna, 2000c, s. 282). Musiki risalelerinin dışında divan şiiri içerisinde de bu makamlar aranabilir. Eğer şiir dilinde saptanabilirlerse bugün örneği olmayan makamların hangi dönemde kullanıldığına dair de ayrıca tespitlerde bulunulmuş olacaktır. 
Basit makamlardan hicaz ve mürekkep makamlardan rahatü'l-ervah makamına dair bir örnek yine Sakıp Dede'nin;

Hicâz semtini tut hoş-makâm ise maksad

Hevâsı râhatü'l-ervâh olur idince mürûr

beytidir.

\section{Musiki Usulleri}

Musikinin temel direklerinden biri olan usul, Türk musikisinde tarih boyunca büyük gelişme göstermiş ve sayıları bir hayli fazla olan özel ritimler oluşturulmuştur. Usul, vuruşlarının değerleri birbirine eşit veya eşit olmayan; ancak mutlaka çeşitli kuvvetli, yarı kuvvetli ve zayıf zamanların belli bir şekilde sıralanmasıyla meydana gelen belli kalıplar hâlindeki sayı veya vuruş gruplarına denmektedir. Vuruş ve zamanların bahsi geçtiği şekilde değişik sıralanması ve ayrıca vuruş değerlerinin de farklı olması, usuller arasında farklılaşmayı meydana getirmiştir. Diğer yandan usulün vurulan her parçasına darp denir ve bu kelime eskiden usul anlamında kullanılmıştır (Özkan, 2017, s. 606). Darp, bu anlamıyla klasik şiirde de kullanılmıştır. İbrahim Hanif'in;

Şikence hâr-1 firâka hamûldür derler

Sükûtu nâtık-1 hüsn-i kabûldür derler

Garîbdir feleğin sâz-kâr-1 dâ'iresi

Makâmına göre darbe usûldür derler (Aksu, 1996, s. 304)

rubaisi, kelimenin karşılığının şiir dilinde verilmiş olmasına bir örnektir.

Usullere makamlarla birlikte riayet edilmesi gerektiğine dair bir örnek de Nâşid'in şu beytidir:

Usûl ile makâmâtın gözet dil-bestegânın hep

Hüseynîye çıkarma nağme-i dil-sûz-1 'uşşâk1 (Zülfe, 1998, s. 152)

Nabi'nin "Ey Nâbî! Musiki ilmi o kadar ilerledi ki okuyucular hata yapmamak için usulüne uygun [bir biçimde] şarkı söylüyorlar." veya "Ey Nâbî! Musiki yolu o kadar inceldi ki okuyucular hataya düşmemek için yavaş bir biçimde şarkı söylüyorlar.” şeklinde mugalata-yı maneviyye sanatı üzere iki farklı biçimde diliçi çevirisi yapılabilecek olan;

Nâbiyâ inceldi râh-1 mûsikî ol rütbe kim

Düşmeyim diye $u$ sûl ile yürür hânendeler (Nâbî, t.y., s. 275a)

şeklindeki meşhur beytinde de yine usule tabi olmanın ne kadar önemli olduğu ile ilgili bilgi verilmiştir. 
Bahsi geçen usullerin bazıları, klasik şiirde de kullanılmıştır. Kâr-1 nâtık formunda yazılmış kimi şiirlerde her beyitte bir usul adı belirtildiğinden usul adlarının bu tür manzumelerde daha çok yer aldığı görülmektedir. Nevres-i Kadim'in divanında yer alan kâr-1 nâtık, buna bir örnek olarak verilebilir (Bk. Akkaya, 1994, s. 523-524). Zira bu şiirde her bir beyitte bir usul ad1 geçmektedir. Arpaemini Sami’nin;

\section{Türk̂̀-darb ile makâm-1 'arabân}

Beste olsa urılur bu dil ü cân (Kutlar Oğuz, 2017, s. 279)

beyti, usullerin şiirde kullanılışına bir başka örnektir. Diliçi çevirisi “Araban makamında Türkîdarp usulü ile bir beste yapılmış olsa bu gönül ve can o besteye kendini kaptırırdı." şeklinde günümüz Türkçesine aktarılabilecek olan beyitte Türkî-darb usulünün geçtiği görülmektedir.

\section{Musiki Çalgıları}

Çalgıların birçoğunun kimi şiirlerde aynı bölümde kullanıldığı görülmektedir. Revani’nin İşretname'sinde geçen "Der-beyân-1 Evsâf-1 Sâz-1 Dil-nüvâz" başlıklı şiiri, musiki çalgılarına dair yazılan şiirlere dönemin önemli çalgılarını ihtiva etmesi bakamından kapsayıcı bir örnektir. Şiirde öncelikle sazendeyi meclise davet eden şair, onun sazıyla cihana şeref geldiğini ve eğlence meclisinde nağmeli söz söyleyebilecek kimsenin o olduğunu belirterek ondan şarkı söylemesini istemiştir. Ardından ise dönem meclislerinin önemli çalgılarının tavsifini yapmıştır.

\section{(mefầîlün mefâ' îlün fe 'îlün)}

Buyur gelsün ne denlü var ise sâz

Açılsun meclis içre perde-i râz

Ki her biri neye olursa kâdir

Hakîkat kimi câdû kimi sâhir

Hemân sihr itmedür çengün kemâli

Ki gökden yire indirmiş hilâli

Hevâya yeltenür her lahza tanbûr

Okusun dirsen anun kulă̆ın bur

Tutamaz 'ûd ile tanbûra pençe

Ne hâcet kendüye vire şikence 
Kaçan tahrîre başlar okur efsûn

Kitâb-1 'aşka mıstar düzdi kânun

Elinde mutribün sanman ki def var

Gam oklarım karşu bir hedef var

'Acep mi 'âlemi tutarsa nâmı

Kemânçe oklı yaylı bir harâmî

Beni anmaga meclisde pey-â-pey

Yine iplük sarar barmagına ney

Kopuz gibi kanı bir hûb-âvâz

Ki sâzun cümlesinden ola mümtâz (Canım, 1998, s. 217-219)

Divan şiirinde ismi geçen musiki çalgıları, her bir çalgının şiirde bağlama kattığı anlam farklı olduğundan türüne göre ayrılmalıdır. Klasik şiirde adları geçen çalgılar; mızraplı çalgılar, yaylı çalgılar, nefesli çalgılar, vurmalı çalgılar ve tuşlu çalgılar olmak üzere beş kısma ayrılabilir.

\subsection{Mızraplı Çalgılar}

Klasik şiirde kopuz, berbat, çeng, tar, şeştar (şeştâ), kanun, tanbur, tanbure, ud, yelteme, santur, saz, cünbüş, çöğür, ikitelli gibi çok sayıda mızraplı çalgı, teşbih ve mecaz yoluyla şiir dilinde kullanılmıştır (Sefercioğlu, 1999, s. 654).

Nedim'in divanında geçen;

Ney ü santur u rebâb ü def ü tanbûr ile çeng

Nağme-i bülbül ü kumrîye olup hem-âheng

Pür eder âlemi şevk u tarab-1 reng-â-reng

Müjdeler gülşene kim vakt-1 çırağan geldi (Macit, t.y., s. 202)

mısralarında dört çalgı adı aynı mısra içerisinde kullanılmış ve bu çalgıların üflemeli çalgılardan ney ve vurmalı çalgılardan def ile birlikte bülbül ve kumruların ötüşlerine uygun ses çıkardıkları belirtilmiştir.

\subsection{Yaylı Çalgılar}

Keman, kemençe, kemane, rebap, murabba gibi çalgılar, divan şiirinde adı geçen yaylı çalgılardandır. Şiirlerinde makam ve çalgıların isimlerini kullanmış olan Nedim'den yine verilebilecek bir başka örnek; 
Geldi yine zühre-i şeker-hand

Destine kemânın eyledi bend

Bir turfa nevâya urdu peyvend

Âgâzesi gerçi kim nihâvend

Ammâ ki karârı ısfahândır (Macit, t.y., s. 180)

bendidir. İcracının eline kemanını almasıyla nihavent makamında çalmaya başladığı, ısfahan makamının güçlü sesi olan neva (re) perdesine indiği ve 1sfahan makamının duraği olan dügâh (la) perdesinde karar ettiğini ifade eden şair, anlaşılacağı üzere yaylı çalgılardan kemanın o anki icrasını belirtmiştir.

\subsection{Nefesli Çalgılar}

Ney, sur, surna, boru, nefir, musîkâr, kaval gibi üflemeli çalgılar da klasik şiir içerisinde kendilerine yer bulabilmişlerdir. Bu çalgıların içerisinde bilindiği üzere en çok ney şiir dilinde kullanılmıştır.

Şeyh Galip'in ney redifli şiirlerinden bir beyit şöyledir:

Çeng ü nefîr her biri mazharıdır bir ârifin

Hazret-i Mevlevîyedir aşkda intimâ-yı ney (Okçu, t.y., s. 404)

Mızraplı çalgılardan çeng ile nefesli çalgılardan nefîr ile neyin yer aldığı beyitte şair, çeng ile nefîrin her birinin bir ârifin izhar olduğu çalgı olduğunu belirtirken neyin intisabının Hz. Mevlana'ya olduğunu ifade etmiştir.

\subsection{Vurmalı Çalgılar}

Çarh, çâr-pare, çegân, daire, def, düblek, kudüm, kûs (kös), makara, nekkâre, tabl gibi çalgılar, klasik şiirde adı geçen vurmalı çalgılardandır (Sefercioğlu, 1999, s. 654). Bu çalgıların içerisinden de bilhassa def ve kudüm çokça kullanılmışlardır. Örneğin Senîh-i Mevlevî’nin def redifli gazelinde yer alan ilk beyit olan;

Olsa da bezm-i tarabda silleden bî-zâr def

Hoş görüp âhengini bozmaz yine nâçâr def (Okyay, 2005, s. 159)

beytinde her ne kadar eğlence meclisinde kendisine vurulmasından bezmiş olsa da çaresiz olan defin yine de bu durumu hoş görüp ahengini bozmadığg ifade edilmiştir.

\subsection{Tuşlu Çalgılar}

Klasik şiirde şu ana kadar tespit edilebilmiş olan tek tuşlu çalgı erganundur. Bu çalgı için bir örnek Sünbülzade Vehbî’nin; 
Semt-i deyrinde döğüp sînemi nâkûs gibi

Erganûn nağmeleri nâle vü efgânımdır (Yenikale, 2017, s. 384-385)

beytidir. Şair, bu beyitte kendi feryatlarını erganun nağmeleri ile ifade etmiştir.

\section{Musiki Çalgılarının Aksamı}

Mızrap, tar, ibrişim, evtar, kiriş, kemane, kulak, mandal, perde, pul, reg, tel, zil, bam, zir gibi kelimeler musiki çalgılarının aksamı olarak divan şiirinde yer almış ve şairler bu aksam ile şiirde anlam ilgisi oluşturmuşlardır. Nedim'in;

Çemende sâzına mızrâb urup yine mutrib

Semend-i şevkimi cüst etdi tâziyâne ile (Macit, t.y., s. 164)

beyti mızrap için bir örnektir ve bu çalgı parçası şiirde çokça kullanılmıştır. Şiir dilinde kullanımında tabii olarak genellikle bir mızraplı çalgının da adı geçmiştir.

\section{Musikinin İcrası ile İlgili Istılahlar}

Musiki nazariyatında musiki icrası ile ilgili adı geçen çok sayıda 1stılah vardır. Bu 1stılahlardan bazıları şiirde adı çok geçen nağme, dem, karar, ahenk, hane, perde gibi 1stılahlardır. Bunların arasından nă̆me, perde ve ahengin şiir dilinde en çok kullanılan 1stılahlardan oldukları görülmüştür. Bir dizinin son sesi olan karar sesi ile ilgili de çok sayıda örnek beyit vardır. Nâşid'in;

Bir hüseynî nă̆mesiyle etdi âheng-i nevâ

Mutribün şevkine pûyân olarak geldi sabâ (Zülfe, 1998, s. 85)

beytinde geçen năgme ve ahenk, bu grup 1stılahlara birer örnektir.

\section{Musiki İcrasında Adı Geçen Şahıslar}

Tasnifin bu başlığg da kendi içerisinde sazendeler, hanendeler, raks edenler ve diğer şahıslar olmak üzere dört kısma ayrılmıştır. Bu kategoride en çok mutrib kelimesinin kullanıldığı görülmüştür. Ancak bu kelime şiirde çalgı çalan ve şarkı söyleyen anlamlarının ikisiyle de kullanılmıştır. Bu nedenle mutrib her iki kategoriye de dâhil edilmiştir.

\subsection{Sazendeler}

Mutrib, avvâd (îdî), Barbed (özel ad, udî), bestekâr, çeng-nevâz, çögürcü, deffâf, dem-sâz, muzrab-zen, tanbûrî, neyzen, defzen, sâzende, râmişger, tel ehli, üstâd, Zühre (Nâhid) gibi isimler klasik şiirde çalgıcı anlamıyla kullanılmışlardır (Sefercioğlu, 1999, s. 663). Nedim’in;

Mutriblerin her rûz u şeb kılsınlar âheng-i tarab

Ammâ usûli feth ü darb olsun makâmı hem 'Acem (Macit, t.y., s. 57)

beyti, mutribin bu kategorideki kullanımına bir örnektir. 


\subsection{Hanendeler}

Hanende, mutrib, Dâvîd, gazel-han, gûyende, hûş-nefes, müterennim, nağme-ger, nağmegüzâr, nă̆me-bahş, nă̆me-perdâz, nă̆me-perver, nă̆me-pîrân, nă̆me-rîz, nă̆me-sâz, nă̆me-tırâz, nă̆me-zen, nevâ-sâz, mugannî gibi kelimeler (Sefercioğlu, 1999, s. 663), klasik şiirdeki şarkı söyleyen ve güzel sesli olanların kendileriyle ifade edildiği isimlerdir. Şeyhülislam Yahya'nın;

Mugannî nă̆meye âgâz idince durmadı zâhid

Mezâk1 olmayanlar savt u elhân ile eğlenmez (Kavruk, t.y., s. 173)

beyti, bu isimlerden mugannînin kullanımına bir örnektir. Şeyh Galip'in;

Bu târîhiyle Gâlib năgme-bahş oldu ney-i hâmem (Okçu, t.y., s. 82)

mısrası ise nă̆me-bahş için bir örnektir.

\subsection{Raks Edenler}

Semazen, rakkas, raksân, çengi gibi şahıslar bu kategoridedir. Bu şahıslara bir örnek yine Nedîm'in bir rubaisinde geçen;

Rakkâs bu hâlet senin oynunda mıdır (Macit, t.y., s. 277)

mısrasındaki rakkastır.

\subsection{Diğer Şahıslar}

Bu grup şahıslar, musiki icrasındaki diğer kişilerdir ve bu şahıslara bir örnek Nâşid'in rubaisinde geçen $e h l-i$ bezm terkibidir.

Tâbiş-i meyden gelip ol gözden âhûya şevk

Şevk-i ruhsârıyla ehl-i bezme geldi tâze şevk

Nâşidâ geh râhatü'l-ervâhda etdi karâr

Mutrib u mey verdi gâhî nă̆me-i şehnâza şevk (Zülfe, 1998, s. 242)

\section{Musiki İcrasında Adı Geçen Mekânlar}

Musiki icrasında mekân olarak değerlendirilebilecek olan ibareler, ya bir yerin adı ya da terkip olarak şiirde görülmektedir. Bu kısım da şu ana kadar tespit edilebilen örneklere bakılarak kendi içerisinde ikiye ayrılmıştır.

\section{1. Ĕglence Meclisleri}

Eğlence meclislerine dair mekânlar, aşağıdaki örneklerde görülen bezmgâh, bezm-i mey, çemen, gülistân, meyhâne gibi ibarelerle şiirde genellikle isim ve terkipler üzerinden verilmiştir. 


\section{Bezmgâh içre mey-i savt-1 'acem}

Ke’s-i tanbûrı ider sâgar-1 Cem (Kutlar Oğuz, 2017, s. 277)

Bezm-i meyde fasl1 ol şûh-1 Nişâbûr eylesün

‘Âşık-1 mehcûrını lutfiyla mesrûr eylesün (Yekbaş, 2014, s. 227)

\subsection{Tasavvufî Meclisler}

Semahane, tekyegâh gibi mekânlar ile tasavvufî mekânlara dair isim ve terkipler ise bu kategoride değerlendirilmelidirler. Şeyh Galip'in;

Bunun şems-i nücûm-1 Zühre'dir yek-pâre şâdîdir

Mukâbildir egerçi çarh-1 bâlâya semâ-hâne (Okçu, t.y., s. 82)

beyti, bu kategorideki mekân adlarından semahane için bir örnektir. Sakıp Dede'nin;

Bezm-i semâ' 1 germ idicek devr-i câm-1 hâl

Sûretde keç-küleh Cem olan Mevlevîlerüz (Ar1, 2018, s. 135)

beyti ise terkiplere dair bir örnektir.

\section{Musiki ile Kurulmuş Deyimler}

Klasik şiirde musiki ıstılahları üzerinden oluşturulan pek çok deyim yer almış ve bu deyimler ile anlam ilgileri kurulmuştur. Sefercioğlu, klasik şiirde geçen çok sayıda deyim tespit etmiş ve bu deyimleri ilgili çalışmasında “Musiki ile İlgili Diğer Unsurlar" başlığı altında incelemiştir. Ancak az sayıda kaynaktan yararlanılarak tespit edilen deyimlerin ayrıca bir başlık olarak değerlendirilmesi ve kendi aralarında da tasnif edilmesi, deyimlerin bağlama kattığı anlamın daha kesin bir biçimde anlaşılmasına ve daha kolay incelenmesine vesile olacaktır. Diğer yandan başka kaynaklara bakıldığında bu deyimlerin dışında daha fazla deyim tespit edilmesi de muhakkaktır. Bu nedenle musiki ile ilgili deyimler ayrıca bir başlık olarak incelenmiştir.

Yapılan sınıflandırmada kimi deyimlerin birden fazla başlıkta değerlendirilebileceği görülmüştür. Örneğin nevâsını sâz etmek deyiminde hem çalgıların genel adı olan sâz hem de musikinin icrası ile ilgili olan nevâ kelimesi yer almaktadır. Şairlerin şiirlerinde bu kadar fazla deyim kullanması hem musiki unsurlarının şiire ne kadar etki ettiğinin hem şairlerin musiki bilgilerini gösterme çabalarının hem de farklı unsurların şiir dilinde birlikte ustalıkla kullanılabildiğinin başka tezahürleridir.

\subsection{Musiki Makam Adları ile Oluşturulmuş Deyimler}

Divan şiirinde makam adlarından faydalanılarak oluşturulmuş olan şehnâz ile muhayyer kılmak, uşşakdan nühüfte kılmak ve buseliği evc eylemek gibi pek çok deyim vardır. Hâtem'in; 
O çâr-ebrû nigâr-1 nâzı zîb-i çâr-gâh itmiş

Olaldan çâr-darb-1 nakşbendî sırrına çesbân (Varışoğlu, 1997, s. 249)

beytinde geçen çâr-gâh etmek musiki makamları ile oluşturulmuş deyimlere bir örnektir. Bu tür deyimler içerisinde en çok kullanılan makamlardan biri de yine uşşak makamıdır. Kadı Burhaneddin'in;

\section{Şehâ 'uşşâkdan kıldım nühüfte}

Ki şehnâz ile k1lursın muhayyer (Ergin, 1980, s. 12)

beytindeki uşşaktan nühüfte kılmak ile Ahmedî'nin;

Nüvâht eyle nevâda kim ol yüzi nev-rûz

Muhayyer eyledi '1şkııla râst 'uşşâk1 (Akdoğan, t.y., s. 585)

beytinde geçen uşşakı muhayyer eylemek bu sınıf deyimlere birer örnektir.

\subsection{Musiki Usulleri İle Oluşturulmuş Deyimler}

Usûl gözetmek, usûl ile yürümek, dâhil-i dâire olmak, çenberden geçmek, devr-i kebîr ile dönmek, der-çenber etmek, devr-i revân eylemek, zencîre çekmek, nîm-devr ile bastırmak gibi deyimler de bu kategoride değerlendirilebilir. Nevres-i Kadîm'in kâr-1 nâtık formundaki şiirinde geçen;

Bir nühüfte nazra ile eyleyüp 'uşşâka nâz

Çekdi zencîre kemend-i kâküli ammâ beni (Akkaya, 1994, s. 524)

beyti, bu deyimlerden zencîre çekmek deyimine bir örnektir.

\subsection{Musiki Çalgılarından Oluşturulmuş Deyimler}

Bu kategorideki deyimler, genellikle musiki çalgılarının genel adı olan saz kelimesi ile ilgilidir. Şiir dilinde çalgılar ile ilgili "âheng-i sâz eylemek, benzini sâz eylemek, çarha girmek, çeng düzmek (tutmak, vurmak), çengin sakalına gülmek, def gibi sîne dövmek (germek), def tutmak, defe dest urmak, gûş̧- rebâbe komak, kânûn etmek, kûs-ı rıhlet etmek, nevâsını sâz etmek, ney gibi âheng kllmak, ney gibi göz kulak olmak, sadâ vermek, sâz depretmek (düzmek, etmek, kılmak), sâz-ı çeng düzmek, sâz-kâr olmak, sâza zahm urmak, sâzına âvâzını şîrin-ter düzmek, sâzına bülbül kondurmak, sâzını düzetmek (pür-sûz eylemek), sâzının âhengini nevrûz eylemek, sözü sâz ile çâre-sâz olmak, sözünü sâz eylemek, şeddini sâz etmek, sîne-saz olmak, ta 'lîm-i sâz eylemek, tanbûrun gûşuna urmak, târ-ı nâleye dem-sâz olmak”' (Sefercioğlu, 1999, s. 663-664) gibi deyimler yer almaktadır.

\subsection{Musiki Çalgılarının Aksamıyla Oluşturulmuş Deyimler}

Çalgıların aksamı ile ilgili deyimlere tel kırmak, teline dokunmak, mızrabı çatır patır 
etmek gibi deyimler örnek olarak verilebilir. Mızraba dair Şeyh Galip divanında geçen bir örnek şöyledir:

Çatır patır ederek nev-zebân-1 mızrâbı

Uyutdu tıfl-1 figânı fesâne-i tanbûr (Okçu, t.y., s. 243)

\subsection{Musikinin İcrasıyla ile İlgili Deyimler}

Sefercioğlu, musiki eserlerinin icrasıyla ilgili çok sayıda deyim tespit etmiştir ve tespit ettikleri içinden bu kategoriye alınabilecek olan deyimler şunlardır: "Âgâz eylemek, âheng etmek (eylemek, kılmak, olmak, tutmak), âheng-i nevâ kılmak, âvâz ile okumak, âvâze kılmak, âvâze salmak, beste bağlamak (etmek, kllmak), b̂̀-âheng olmak, cünbüşvermek, çalınmak, çıkıs vermek, dem-sâz etmek (geçinmek, olmak), dest urmak, devr eylemek, dile getirmek, dumrısı oynatmak, düzen vermek, ezgiye düzmek, gazel âgâz kllmak, gazel demek, gazel inşâd kılmak, gazel okumak, gazel taksîm etmek, gazel tasnîf etmek, gulgul etmek (eylemek), gûş tutmak, gûş̧âl vermek, gûşmâle çekmek, gülbang çekmek, hâne geçmek, harf atmak, hem-âheng olmak, hem-âvâz etmek, hem-dem olmak, hem-nefes olmak, hevâ-dâr olmak, icrâ etmek (olunmak), işret sürmek, karâr etmek (vermek), kulağa çalınmak, kulağını burmak (bükmek), mahmûr okumak, makâma dönmek (gelmek), makâmât okumak, meclisi pür-sûz etmek, mersiye okumak, mevzûn okumak, murabba bağlamak, mükerrer etmek, nagam etmek, nagamât eylemek, nagamâta âgâz eylemek, nağme âgâz eylemek, nă̆me düzmek (etmek, eylemek), nağme-sâz olmak, nağmeye ser-âgâz etmek, nă̆meye karar vermek, nağmeyi istimâ eylemek, nağmeyi terkibe komak, nakş bağlamak, nakş-ı tarâb-efzâ eylemek, nakş u tasnîfe âgâz eylemek, nâleye âgâz etmek, nâra çekmek, nefes etmek (urmak), negam düzetmek (etmek), nevâ düzmek (eylemek, kllmak), nevâ-sâz eylemek, nevaht etmek (klmak), perde bağlamak, perde-birûn olmak, perde-dûz olmak, perde-küşâ-yı esrâr olmak, perde-sâz-ı bâb olmak, perdede gulgule olmak, perdeden çıkmak (çıkarmak), perdeye saklanmak, pest eylemek, pîş-rev olmak, raksa girmek, ser-âgâz etmek (eylemek, olmak, öğrenmek), seyr eylemek, şîven etmek, taksîm etmek, ta 'lîm olmak, tâze hevâ bağlamak, tâze nevâ bağlamak, tazŷi-i nefes eylemek, tebdîl-i makâm etmek (eylemek), terâne bağlamak (eylemek), terâne-senc olmak, terâne sencân-ı neşât olmak, terennüm etmek (eylemek, kllmak), terennüme âgâz etmek (başlamak), yek sâz-kâra düşmek, zebân vermek” (Sefercioğlu, 1999, s. 663-664).

Bu başlık altında sırasıyla Cevrî, Enis Recep Dede ve Ziya Paşa'dan verilebilecek örnek beyitler şunlardır:

Gül-i ra'nâya döner gûş idenün reng-i ruhı

Eylese nağmeyi terkîbe koyup bestenigâr (Ayan, 1981, s. 111)

Gûş-1 câna eser itse ne aceb savt-1 hazîn

Sîne tanbûrının ol nağme-i zîr ü bamıdır (Ceyhan, 1990, s. 60),

Bir yerde ki yok nağmeni takdîr edecek gûş

Tazyî‘-i nefes eyleme tebdîl-i makâm et (Tanyaş, 1995, s. 104) 


\subsection{Tekke Musikisi ile İlgili Deyimler}

Bu deyimlerin içerisinde ayrıca tasavvufi unsurların yer aldığı deyimler de söz konusudur. Semâ etmek, semâya girmek, vird-i ney okumak, ney gibi nâlân olmak gibi deyimler de sınıflandırmanın bu başlığında değerlendirilmiştir. Şemseddin Sivasî’nin Gülşen-âbâd mesnevisinde yer alan;

Sirâyet eylemiş hâlât-1 ezkâr

Semâ‘ itmek diler hâletle nâ-çâr (Aksoy, 1985, s. 149)

beyti de bu grup deyimler için bir örnektir.

\section{SONUÇ}

Divan edebiyatında şairlerin duygu ve düşüncelerini ifade etmede yararlandıkları unsurlardan biri de musiki ıstılahlarıdır. Klasik şiir içerisinde farklı başlıklar altında incelenebilecek bu kadar çok musiki unsurunun yer alması, bestelenmiş çok sayıda klasik şiir örneğinin bulunması gibi hususlar, her iki ilmin birbirinden ne kadar çok beslendiğinin bir kanıtıdır. Ayrıca her iki ilmin hem sosyal hayattan ne kadar beslendiğinin hem de sosyal hayata ne kadar unsur kattığının başka örnekleri de yine bu unsurların kullanıldığı şiirlerde yer almaktadır.

Yapılan literatür taramasında bu unsurların çeşitlilik arz ettiği ve bu nedenle tasnif edilmesi gerektiği anlaşılmıştır. Şiirde en çok kullanılan musiki unsurlarının makam, usul ve çalgı adları ile çalgıların aksamı olduğu görülmüştür. Bunların haricinde musiki icrası ile ilgili de pek çok ıstılah vardır. Musiki icrasındaki şahıslar ve mekânlar, tasnifin diğer başlıklarındandır. Şiir dilinde adları geçen makam ve çalgı adları ile musiki icrasındaki şahıslar ve mekânların kendi içerisinde tasnif edilmesi ile şiirlerde geçen bu unsurların ait olduğu başlığın genel özelliklerini verebileceği de düşünülmüştür. Bu nedenle bu unsurlar, alt başlıklar hâlinde incelenmiştir.

Musiki unsurları ile klasik şiir içerisinde çok sayıda kurulmuş deyim bulunduğu da anlaşılmıştır. Ancak bu deyimleri yorumlamak için klasik şiir bilgisinin dışında klasik Türk musikisi bilgisinin de gerekli olduğu düşünülmektedir. Zira şairler, kimi zaman duygu ve düşüncelerindeki değişimleri bu unsurlar ile kurulmuş deyimlerle ifade etmişlerdir. Örneğin "uşşâkı muhayyer eylemek" ya da "uşşâkın nağmesini hüseynîye çıkarmak" gibi deyimlerin arka planında nazariyat bilgisine göre yorumlanıp yorumlanamayacağı da tartışılmalıdır. Çünkü bu deyimlerde muhayyer ya da hüseynî makam adlarının kullanılmış olmasının nedeni, âşıkların ağıt veya feryatlarının daha da yükselmiş olduğunun ifadesi olmalıdır.

Klasik edebiyat şairleri, şiirin kelime kadrosunu zemindeki manayı inşa etmek üzere kullanmışlardır. Tasnifte ilk olarak yer alan musiki makamları bu hususta önemli örneklerdendir. Klasik Türk müziğinde altı yüzden fazla makam olduğu bilinmektedir. Elbette altı yüz makamın tamamının adı klasik şiirde geçmemektedir. Ayrıca klasik Türk müziğinde bestelenmiş herhangi bir eserinin günümüze ulaşmadığı pek çok makam da vardır. Bu kadar çok makam olması ve bu 
makamların isimlerinin tam olarak bilinmemesi nedeniyle bazı divan neşirlerinde okumalarda yanlışlıklar olduğu da görülmüştür. Klasik edebiyat ile klasik Türk musikisi alanlarının birlikte ve ayrıntılı olarak değerlendirildiği çalışmaların artması ile her iki alan da ilgili ıstılahları tanıyacak ve bu unsurların hangi bağlamda değerlendirilmesi gerekliliği de yeni çalışmalarla daha da netlik kazanacaktır. Bu şekilde yapılacak olan çalışmaların sadece edebiyatta musiki unsurlarının nasıl yer aldığına dair yorumlamaların yapılmasında değil aynı zamanda güfte ve beste uyumu gibi farklı yönlerden de incelemelere katkısı olacaktır. Bunların dışında edebi metinlerde makamlara verilen anlamların ayrıntılı olarak incelenmesi ile makamların hissiyatı hakkındaki mevcut bilgilere de katkı sağlanabilecektir.

Yapılabilecek olan ayrıntılı çalışmada musiki ıstılahlarına dair önemli tespitler yapılacağı da muhakkaktır. Örneğin bu sstılahların geçtiği şiirler incelendiğinde herhangi bir makamın şiir diline ne zaman girmiş olabileceğine dair de bilgi edinilebilecektir. Böylelikle bu tür makamların şiir dilinde yer alıp almadığg ile ilgili de tespitlerde bulunulabilecektir.

Bu zamana kadar musiki ıstılahlarına dair yapılmış kimi çalışmaların dışında araştırmalarda genellikle eserlerde hangi istılahların yer aldığına dair tespitlerde bulunulduğu görülmüştür. Bunun dışında 1stılahlar edebî sanatlar yönünden de incelenmiştir. Bahsi geçen unsurların yer aldığı bir manzumede nasıl bir manayı sağladığı ile ilgili çalışmalarda ise kısmi bilgiler vardır. Divan şiirinde adları yer alan musiki ıstılahlarının bu şekilde tasnifi ve her bir tasnifin genel özelliklerinin çıkarılması ile klasik edebiyat metinlerinin anlaşılmasına da bir katkı sağlanacaktır. Ancak geniş malzemeyi ihtiva eden bu unsurlar ile ilgili ayrıntılı bilgi yapılabilecek olan daha kapsamlı bir çalışma ile mümkün olacaktır. Bu çalışmada ise divan şiirinde isimleri geçen musiki ıstılahları tasnif edilmiştir. Böylece bundan sonraki süreçte manzum ya da mensur eserlerde tespit edilen 1stılahların tasnifte verilen bir başlığın altında değerlendirileceği ve bu sayede bu 1stılahlara dair geniş bir malzemenin yer aldığı sistemli bir literatürün zamanla ortaya çıkacağı düşünülmektedir. Bu nedenle oluşturulmak istenen araştırma problemi ile ilgili ortaya konulması gereken tespitler, bu veya buna benzer bir başlık altında her iki alanın uzmanlarınca yapılabilecek disiplinlerarası bir çalışmaya ya da her iki alan üzerinde söz sahibi olan bir araştırmacının yapabileceği ayrıntılı bir çalışmaya bırakılmıştır.

\footnotetext{
Hakem Değerlendirmesi: Dış bağımsız.

Çıkar Çatışması: Yazar çıkar çatışması bildirmemiştir.

Finansal Destek: Yazar bu çalışma için finansal destek almadığını beyan etmiştir.

Peer-review: Externally peer-reviewed.

Conflict of Interest: The author has no conflict of interest to declare.

Grant Support: The author declared that this study has received no financial support.
} 


\section{KAYNAKÇA/REFERENCES}

Akdoğan, Y. (t.y.). Ahmedî Dîvân. Ankara: Kültür ve Turizm Bakanlığı Yayınları. Erişim tarihi 04 Eylül 2020, https://ekitap.ktb.gov.tr/Eklenti/10591,ahmedidivaniyasarakdoganpdf.pdf?0

Akkaya, H. (1994). Nevres-i Kadîm ve Türkçe Divanı [Doktora Tezi]. Marmara Üniversitesi, Sosyal Bilimler Enstitüsü.

Aksoy, H. (1985). Şemsi’nin Gülşen-âbâd Mesnevîsi. Marmara Üniversitesi İlahiyat Fakültesi Dergisi, 3, 125-177.

Aksu, C. (1996). İbrahim Hanif Divanı [Yüksek Lisans Tezi]. İstanbul Üniversitesi, Sosyal Bilimler Enstitüsü.

Alpay, A. İ. (1992). Nahifi Süleyman Efendi (Hayatı, Eserleri, Edebî Kişiliği ve Divanı'nın Tenkitli Metni) [Doktora Tezi]. Selçuk Üniversitesi, Sosyal Bilimler Enstitüsü.

Altunmeral, M. (2011). Abdî’nin Gül ü Nevrûzunda Mûsikî Terimleri. Celal Bayar Üniversitesi Sosyal Bilimler Dergisi, 9(2), 325-332.

Arı, A. (2018). Sâkıb Dede (Mevlevîlikte Bir Hanedanlık Kurucusu) Dîvân. Ankara: Kültür ve Turizm Bakanlığı Yayınları. Erişim tarihi 04 Eylül 2020, https://ekitap.ktb.gov.tr/Eklenti/59860,sakib-dededivanipdf.pdf?0

Arslan, M. (1992a). Kadı Burhaneddin Dîvanında Mûsikî. Yedi İklim Dergisi, 32, 15-23.

Arslan, M. (1992b). Nedîm Dîvanı'nda Mûsikî. Klzılırmak Dergisi, 11, 5-10.

Aslan, M. U. (2017). Tokatlı Kânî Dîvânında Mûsikî İle İlgili Unsurlar. Rast Müzikoloji Dergisi, 5(1), 1490-1499.

Ayan, H. (1981). Cevrî Hayâtı, Edebî Kişiliği, Eserleri ve Divanının Tenkidli Metni. Atatürk Üniversitesi Yayınlar1.

Bilgin, E. (2019). Klâsik Şiirde Manayı Sağlayan Bir Unsur Olarak Mûsikî Makamlarının Kullanılışına Dair Bazı Örnekler. İçinde Türk Dili ve Edebiyatı Bilgi Şöleni Sempozyumu (21-23 Haziran 2019) Bildiriler (ss. 349-359). Atatürk Üniversitesi Yayınları.

Canım, R. (1998). Türk Edebiyatında Sakinâmeler ve İşretnâme (1. Basım). Akçağ Yayınları.

Ceyhan, Â. (1990). Enis Receb Dede (? - 1733) Hayatı, Edebi Şahsiyeti ve Eserleri: Divanı [Yüksek Lisans Tezi]. Marmara Üniversitesi, Sosyal Bilimler Enstitüsü.

Çalka, Mehmet Sait. (2008). “Nev’î Divânında Mûsikî Terimleri”. Turkish Studies, 3(2), 179-193.

Çetin, K. (2009). Musikî ve Musikî Terimlerinin İbrahim Râş̧id Divanı'ndaki Yansımaları. Turkish Studies, $4(2), 199-225$.

Erdoğan, M. (2010). Divan Şiirinin Kaynaklarından Musiki İlmi ve Musiki Terimleriyle Yazılmış Bazı Manzumeler. Uluslararası Sosyal Araştırmalar Dergisi (Klâsik Türk Edebiyatının Kaynakları Özel Saylsı -Prof. Dr. Turgut Karabey Armağanı-), 3(15), 28-55.

Ergin, M. (1980). Kadı Burhaneddin Divanı. İstanbul Üniversitesi Edebiyat Fakültesi Yayınları.

Kavruk, H. (t.y.). Şeyhülislâm Yahyâ Dîvânı. Ankara: Kültür ve Turizm Bakanlığı Yayınları. Erişim tarihi 04 Eylül 2020, https://ekitap.ktb.gov.tr/Eklenti/10655,seyhulislamyahyadivanihasankavrukpdf.pdf?0

Kutlar Oğuz, F. S. (2017). Arpaemîni-zâde Mustafa Sâmî Dîvân. Ankara: Kültür ve Turizm Bakanlığı Yayınları. Erişim tarihi 04 Eylül 2020, https:/ekitap.ktb.gov.tr/Eklenti/56084,arpaeminizade-mustafasami-divanipdf.pdf?0

Nâbî. (t.y.-a). Dîvân-ı Nâbî. Süleymaniye Kütüphanesi, Hamidiye.

Nabi. (2018). Hayrâbâd (M. Gökcan \& H. Koç, hzl.). Ankara: Kültür ve Turizm Bakanlığı Yayınları. Erişim tarihi 08 Eylül 2020, https://ekitap.ktb.gov.tr/Eklenti/59849,nabi-hayrabadpdf.pdf?0 
Okçu, N. (t.y.). Şeyh Gâlib Dîvânı. Kültür ve Turizm Bakanlığı Yayınları. Erişim tarihi 04 Eylül 2020, https://ekitap.ktb.gov.tr/Eklenti/10654,metinpdf.pdf?0

Okyay, E. (2005). Senîh-i Mevlevî Divanı [Yüksek Lisans Tezi]. Çanakkale Onsekiz Mart Üniversitesi, Sosyal Bilimler Enstitüsü.

Özkan, İ. H. (2017). Türk Mûsikîsi Nazariyatı ve Usûlleri Kudüm Velveleleri (8. Basım). Ötüken Neşriyat.

Öztuna, Y. (2000a). Basit Makam. İçinde Türk Mûsikîsi Kavram ve Terimleri Ansiklopedisi (s. 32). Atatürk Kültür Merkezi Başkanlığı Yayınları.

Öztuna, Y. (2000b). Müberkaa. İçinde Türk Mûsikîsi Kavram ve Terimleri Ansiklopedisi (s. 279). Atatürk Kültür Merkezi Başkanlığı Yayınları.

Öztuna, Y. (2000c). Mürekkeb Makam. İçinde Türk Mûsikîsi Kavram ve Terimleri Ansiklopedisi (ss. 280284). Atatürk Kültür Merkezi Başkanlığı Yayınları.

Öztuna, Y. (2000d). Nihâvend. İçinde Türk Mûsikîsi Kavram ve Terimleri Ansiklopedisi (ss. 300-301). Atatürk Kültür Merkezi Başkanlığı Yayınları.

Say, A. (1985). Dizi. İçinde Müzik Ansiklopedisi (C. 2, s. 446). Sanem Matbaası.

Sefercioğlu, M. N. (1999). Dîvan Şiirinde Mûsikî ile İlgili Unsurların Kullanılışı. İçinde Osmanlı Ansiklopedisi (C. 9, ss. 649-668). Yeni Türkiye Yayınları.

Tanyaş, H. (1995). Băgdatlı Ruhi ve Ziya Paşa Terkib-i Bentler ve Terci-i Bent (Esas Metin ve Manzum Çeviriler) (1. Basım). Kavaklıdere Kültür Yayınları.

Tozlu, M. (2014). Âsım Dîvânı'nda Mûsikî Unsurları. Divan Edebiyatı Araştırmaları Dergisi, 2(13), 141-141.

Varışoğlu, M. C. (1997). Hâtem Hayatı, Edebî Şahsiyeti, Divanının Tenkitli Metni ve İncelemesi [Yüksek Lisans Tezi]. Atatürk Üniversitesi, Sosyal Bilimler Enstitüsü.

Yekbaş, H. (2014). Fihrist-i Makâmât Ahmed Avni Konuk’a mı Aittir? Türk Kültürü Incelemeleri Dergisi, 31, 205-238.

Yenikale, A. (2017). Sünbülzâde Vehbî Dîvânı. Ankara: Kültür ve Turizm Bakanlığg Yayınları. Erişim tarihi 04 Eylül 2020, https:/ekitap.ktb.gov.tr/Eklenti/56212,sunbulzade-vehbi-divanipdf.pdf?0

Zülfe, Ö. (1998). Nâşid (1749-1791) Dîvân) [Yüksek Lisans Tezi]. Marmara Üniversitesi, Sosyal Bilimler Enstitüsü. 
